\title{
Monitoring tumor antigen specific T-cell responses in cancer patients and phase I clinical trials of peptide-based vaccination
}

\begin{abstract}
Numerous phase I and II clinical trials testing the safety and immunogenicity of various peptide vaccine formulations based on CTL-defined tumor antigens in cancer patients have been reported during the last 7 years. While specific T-cell responses can be detected in a variable fraction of immunized patients, an even smaller but significant fraction of these patients have objective tumor responses. Efficient therapeutic vaccination should aim at boosting naturally occurring antitumor T- and B-cell responses and at sustaining a large number of tumor antigen specific and fully functional effector $\mathrm{T}$ cells at tumor sites. Recent progress in our ability to quantitatively and qualitatively monitor tumor antigen specific CD8 T-cell responses will greatly help in making rapid progress in this field.
\end{abstract}

Keywords Cancer vaccines - Tumor immunology • Immune monitoring $\cdot$ Tetramers

\section{The concept of defined therapeutic cancer vaccines}

The identification of tumor-associated antigens recognized by cytolytic T lymphocytes (CTLs) at the molecular level formed the basis for the design of well-defined

This work was presented at the first Cancer Immunology and Immunotherapy Summer School, 8-13 September 2003, Ionian Village, Bartholomeio, Peloponnese, Greece.

P. Romero $(\bowtie) \cdot$ D. E. Speiser

Divison of Clinical Onco-Immunology, Lausanne branch, University Hospital (CHUV), Ludwig Institute for Cancer Research, Lausanne, Switzerland

E-mail: pedro.romero@isrec.unil.ch

Tel: $+41-21-3140176$

Fax: +41-21-3147477

J. Cerottini

Lausanne Branch, Ludwig Institute for Cancer Research, Epalinges, Switzerland therapeutic cancer vaccines. Indeed, a growing number of phase I and II clinical trials are being performed and reported during the last decade. Some of the most often used approaches to experimental vaccination in human cancer patients include the use of synthetic peptides administered either free in aqueous solution or together with adjuvants, highly purified recombinant proteins, recombinant viral or bacterial vectors and autologous dendritic cells either loaded with peptides, proteins, or infected with recombinant vectors or even fused with tumor cells. In contrast to all the other vaccine delivery systems for CTL-defined antigens, peptides are by far the simplest compounds that lend themselves to rigorous chemical definition and pharmacological formulation. However, at the same time, peptides by themselves are rather weak immunogens. Hence the need to add immune adjuvants to boost their immunogenicity. In this minireview we will focus on the recent reports on clinical trials of peptide vaccination (Table 1). The majority of these trials share two common outcomes. On the one hand, specific immune responses were induced in a variable proportion of vaccinated patients, ranging from about $50 \%$ to $80 \%$ in some reports. On the other hand, a smaller proportion of vaccinated patients had measurable clinical benefit. In general the rate of clinical responses is not superior to $10-20 \%$.

\section{The hurdles for cancer vaccines based on CTL-defined tumor antigens}

Although therapeutic vaccination in cancer patients does lead to the induction of specific immunity in a significant but variable proportion of patients, consistent immunization leading to induction of CTL responses in all vaccinated patients remains to be achieved. More importantly, the low but significant level of clinical efficacy in the trials reported thus far suggests a lack of correlation between specific immunity measured in blood cells and antitumor effect. Thus, the 
Table 1 Clinical trials of tumor antigenic peptide-based vaccination in mostly, but not exclusively, metastatic melanoma

\begin{tabular}{|c|c|c|c|c|c|}
\hline Peptide & HLA & Adjuvant & CTL & $\begin{array}{l}\text { Tumor } \\
\text { response }\end{array}$ & Reference \\
\hline $\begin{array}{l}\text { MAGE-A } 3168-176 \\
\text { Same peptide or recombinant } \\
\text { minigene virus }\end{array}$ & A1 & None & $\begin{array}{l}\text { Not detected } 4 / 9 \text { regressors } \\
\text { and } 1 / 14 \text { progressors }\end{array}$ & $7 / 25$ & {$[42][13]$} \\
\hline 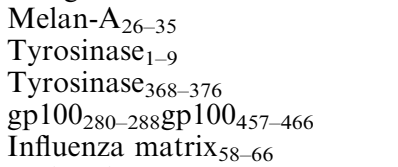 & A2 & $\begin{array}{l}\text { None or } \\
\text { GM-CSF }\end{array}$ & $3 / 62 / 60 / 60 / 6$ & $3 / 3$ & {$[43]$} \\
\hline Melan- $\mathrm{A}_{27-35}$ & A2 & IFA & $\begin{array}{l}12 / 1815 / 18 \\
\text { by IFN- } \gamma \text { release }\end{array}$ & $0 / 23$ & {$[24]$} \\
\hline gp100 $209-217$ & A2 & IFA & $2 / 8$ & $1 / 19$ & {$[25]$} \\
\hline $\mathrm{gp} 100_{209-217(\mathrm{~T} 210 \mathrm{M})}$ & A2 & IFA & $10 / 11$ & $0 / 11$ & [25] \\
\hline $\mathrm{gp} 100_{209-217(\mathrm{~T} 210 \mathrm{M})}$ & A2 & IL-2 + IFA & $3 / 19$ & $8 / 195 / 12$ & {$[25]$} \\
\hline $\begin{array}{l}\text { MUC-1 peptide } \\
\text { conjugated to KLH }\end{array}$ & $\begin{array}{l}\text { A1 } \\
\text { A2, } \\
\text { A1 }\end{array}$ & Detox-B & $7 / 11$ & Not reported & {$[44]$} \\
\hline $\begin{array}{l}\text { gp100 } 209-217(\mathrm{~T} 210 \mathrm{M}) \\
\text { Tyrosinase }_{368-376}(370 \mathrm{D})\end{array}$ & A2 & $\mathrm{IFA} \pm \mathrm{IL}-12$ & $\begin{array}{l}33 / 38 \text { by IFN- } \gamma \text { ELISA } \\
37 / 42 \text { by tetramer } \\
\text { assay }\end{array}$ & Inconclusive & {$[45]$} \\
\hline $\begin{array}{l}\text { HPV16 E7 } 11-20, E 7_{86-93} \\
\text { Pan-DR binding peptide }\end{array}$ & A2 & IFA & ND & $2 / 19$ & [46] \\
\hline $\begin{array}{l}\text { Bcr-abl breakpoint } \\
\text { peptides ( } 5 \text { peptides) }\end{array}$ & Various & QS-21 & $\begin{array}{l}\text { Undetectable CTL } \\
\text { proliferative responses }\end{array}$ & Not reported & {$[47]$} \\
\hline Tyrosinase peptides & $\mathrm{A} 1, \mathrm{~A} 2, \mathrm{~A} 3$ & GM-CSF & $4 / 7$ & $1 / 5$ & [48] \\
\hline $\mathrm{HPV} E 7_{12-20}$ & $\mathrm{~A} 2$ & IFA & $10 / 16$ & $3 / 18$ & [49] \\
\hline HER-2369-384, 688-703, 971-984 & A2 & GM-CSF & $10 / 15,5 / 15,12 / 15$ & Not reported & {$[50]$} \\
\hline $\begin{array}{l}\text { gp100 } 209-217(\mathrm{~T} 210 \mathrm{M}) \\
+ \text { HPV16 E7 } \\
11-20\end{array}$ & A2 & IFA & $28 / 29$ & Not applicable & {$[14]$} \\
\hline $\begin{array}{l}\text { gp100 } 109-217(\mathrm{~T} 210 \mathrm{M}) \\
\text { and Melan-A } \\
\pm \mathrm{gp} 100_{44-59}\end{array}$ & A2DRB1*0401 & IFA & $\begin{array}{l}\text { 18/19 (gp100) and 0/18 } \\
(\text { Melan-A de novo) } 7 / 10 \\
(\text { gp100)0/10 } \\
\text { (new anti-Melan-A) }\end{array}$ & $0 / 221 / 19$ & {$[51]$} \\
\hline MAGE-A12 ${ }_{170-178}$ & $\mathrm{Cw}^{*} 0702$ & IFA & Not detected & $1 / 9$ & {$[52]$} \\
\hline $\begin{array}{l}\text { gp100 } \\
\text { Melan-217(T210 M) } \\
\text { Tyrosinase } 35 \text { (A27L) } \\
\text { Ty-376 (370D) }^{26}\end{array}$ & A2 & $\begin{array}{l}\text { IFA + SD-9427 } \\
\text { (Progenipoietin) }\end{array}$ & $\begin{array}{l}7 / 10 \text { by IFN- } \gamma \text { to at least } \\
\text { one or more peptides } 11 / 12 \\
\text { by tetramer assay (after } \\
\text { in vitro stimulation) }\end{array}$ & $\begin{array}{l}\text { Tumor free } \\
\text { at study entry } \\
4 / 15 \text { relapsed } \\
\text { with a median } \\
\text { follow-up } \\
\text { of } 20 \text { months }\end{array}$ & [53] \\
\hline $\begin{array}{l}\text { One to four } \\
\text { tumor-associated peptides }\end{array}$ & $\mathrm{A} 2$ or $\mathrm{A} 24$ & IFA & $\begin{array}{l}\text { 7/14 by IFN- } \gamma \text { ELISA; } \\
8 / 12 \text { by serology (IgG) }\end{array}$ & $\begin{array}{l}\text { No objective } \\
\text { tumor responses } \\
\text { reported }\end{array}$ & {$[54]$} \\
\hline Melan-A $27-35$ & A2 & $\begin{array}{l}\text { Peptide } \\
\text { pulsed autologous } \\
\text { PBMCs }+ \text { rhIL-12 }\end{array}$ & $\begin{array}{l}12 / 18 \\
15 / 18 \text { by IFN- } \gamma \\
\text { release }\end{array}$ & $7 / 20$ & {$[55]$} \\
\hline $\begin{array}{l}\text { gp100 } 209-217(\mathrm{~T} 210 \mathrm{M}) \\
\quad+\mathrm{gp} 100_{280-288(\mathrm{~A} 288 \mathrm{~V})}\end{array}$ & $\mathrm{A} 2$ & $\begin{array}{l}\text { IFA and systemic } \\
\text { anti-CTLA-4 }\end{array}$ & $11 / 116 / 11$ & $\begin{array}{l}3 / 14 \\
\quad+\text { severe } \\
\text { autoimmunity }\end{array}$ & {$[56]$} \\
\hline
\end{tabular}

hurdles ahead for the development of effective therapeutic cancer vaccines are considerable and include (1) identification of "universal" tumor rejection antigens, (2) optimization of vaccination procedures, (3) quantitative monitoring of Ag-specific CTL responses, (4) identification of the type of protective CTL response(s), and (5) understanding tumor escape pathways.

The ideal tumor antigen for vaccination

Such antigens should display selective expression by all tumor cells and not by normal tissues; their expression should be essential for tumor cell survival; they should be targeted by both CD8 and CD4 T cells; and their recognition should be restricted by the most frequently expressed HLA alleles. Moreover, the corresponding peptides should be efficiently processed by the tumor cells and achieve a high density as MHC-peptide complexes at the surface of the tumor cells, and the level of immunological tolerance to these antigens should be minimal. It is clear that, for the time being, there are no tumor antigens that fulfill these stringent conditions. Thus, there is room for tumor antigen identification. In the meantime, the relatively large number of tumor antigens allows us to 
choose those that come close to meeting the criteria listed above.

\section{Therapeutic cancer vaccine optimization}

The main goal today for the optimization of therapeutic cancer vaccines should be to achieve a $100 \%$ success rate in the induction of specific T-cell mediated immunity. In this regard, the use of molecularly defined tumor antigens for vaccination offers the opportunity to monitor the optimization process. The variables include the choice of the delivery system-naked DNA, recombinant vectors, short peptides, long peptides, recombinant protein or autologous dendritic cells loaded with an appropriate form of antigen-dose, route of administration, frequency of vaccination, and immunological adjuvants. Although, some of these parameters could be addressed in HLA transgenic mouse models, the most direct way for vaccine optimization is the implementation of well-planned, small phase I/II clinical trials with defined immune response endpoints.

\section{Monitoring tumor antigen-specific CTL responses in vaccination}

Unlike most prophylactic vaccines against infectious pathogens that aim at the induction of a predefined level of neutralizing antibodies, therapeutic vaccines based on CTL-defined antigens aim at inducing a specific CTL response. Simple and reliable assays to accurately measure antibody levels have been available to clinical immunologists for decades. They are routinely used in the clinics as well as in large scale clinical trials of vaccination $[1,2,3]$. In sharp contrast, assays to measure directly the numbers as well as the quality of antigenspecific $T$ cells only became available 7 years ago. The introduction of soluble fluorescent class I MHC-peptide complexes, commonly known as tetramers or multimers, allowed us to enumerate CTLs and determine their relative frequencies directly ex vivo using flow cytometry [4]. However, they do not provide information on the differentiation stage of antigen-specific $\mathrm{T}$ cells. In this regard, the parallel development of single cell cytokine release assays has allowed us to simultaneously assess the effector capabilities of $\mathrm{T}$ cells of defined specificity. ELISpot assays for cytokine-producing $\mathrm{T}$ cells enable the rapid and relatively sensitive enumeration of $T$ cells but do not provide direct information on the fraction of antigen-specific $\mathrm{T}$ cells with cytokine production capability. Flow cytometry-based cytokine-release assays offer the possibility to combine detection of single cytokine-secreting cells, with identification of those $\mathrm{T}$ cells binding defined class I MHC-peptide multimers. Two such assays exist which have been shown to fulfill this purpose: intracellular cytokine staining [5] and cytokine release assays [6]. The latter permits the visualization of intact cytokine-secreting antigen-specific
T cells which can be isolated by flow cytometry cell sorting for analysis or for adoptive transfer immunotherapy [7]. In addition to cytokine production, $T$ cells can also be characterized in terms of their cell surface phenotype. The expression of surface antigens such as CD45RA, CD45RO, CD27, CD28, and CCR7 allows us to establish correlations with their functional state of differentiation $[8,9,10]$. The expression of molecules associated with T-cell effector function can also be quantitated by intracellular staining such as perforin and granzyme B. Although, there are no single cell assays for the detection of multimer ${ }^{+} \mathrm{T}$ cells with lytic function, some recent methods designed to detect target cell apoptosis by flow cytometry may be useful to develop them [11].

Despite the advances in recent years in accurate monitoring of antigen-specific CD8 T-cell responses, progress is still needed. The assays remain labor intensive and are difficult to standardize. The high number of cells required limits the number of assays that can be performed. Moreover, the circulating lymphocyte pool is the only compartment readily accessible for monitoring specific T-cell responses, although it may not be the most relevant in terms of establishing correlations with clinical tumor response. An important limitation at present relates to the sensitivity of these assays which is in the order of approximately 1 in 10,000 $\mathrm{CD}^{+} \mathrm{T}$ lymphocytes. It is becoming clear that the frequency of tumor antigen-specific CD8 T cells is frequently below this limit of detection, even after repeated vaccination. Hence the common practice in monitoring current clinical trials of vaccination of introducing steps of in vitro antigen-driven amplification of $\mathrm{T}$ cells before measurement of multimer ${ }^{+} \mathrm{T}$ cells, or of specific cytokine release assay. Thus, most of the valuable information on in vivo frequency and functional differentiation of $\mathrm{T}$ cells upon vaccination is lost. A solution to this problem has been devised recently in a study quantitating the frequency of MAGE-3.A1-specific $T$ cells before and after vaccination $[12,13]$. It involves two or three rounds of in vitro stimulation with peptide in multiple single cell dose microcultures combined with detection of expanding specific $T$ cells in individual microcultures by flow cytometry with multimers. This method has been used to estimate the frequency of antigen-specific $\mathrm{T}$ cells, although it is not a complete limiting dilution analysis. While this approach is quite labor intensive, it allows us to monitor T-cell activation at low T-cell frequencies. Hopefully, the learning process on vaccine optimization will lead to the consistent induction of high frequency systemic CTL responses in the future so that their direct and accurate monitoring with the modern tools described above will be possible.

We have used fluorescent HLA-A2 multimers carrying several of either cancer/testis or melanocyte/melanoma differentiation antigenic peptides to assess the naturally acquired CTL response to various tumor antigens. To establish baseline values of frequency of tumor antigen specific $T$ cells in cancer patients, we measured the numbers of multimer ${ }^{+} \mathrm{T}$ cells in 
peripheral blood lymphocytes (PBMCs) in series of HLA-A2 metastatic melanoma patients. The experimentally determined sensitivity of multimers varies from 1 in 2,000 to 1 in $10,000 \mathrm{CD} 8^{+}$PBMCs $(0.05-0.01 \%)$. Memory $\mathrm{T}$ cells directed against dominant viral epitopes such as influenza matrix 58-66, Epstein-Barr virus BMLF $280-288$, or CMV pp65 495-503 are readily detectable above this detection limit in a high proportion of individuals. In contrast, generally, multimer ${ }^{+} \mathrm{T}$ cells for gp100 [14], tyrosinase [15], MAGE-A10 [16], NY-ESO-1 [17], or SSX-2 [18] can not be detected directly ex vivo, but only after expansion by repeated in vitro stimulation with the antigenic peptide on appropriate antigen-presenting cells. Some exceptions involving the tyrosinase antigen have been reported in advanced metastatic melanoma patients. In one case, the multimer ${ }^{+} \mathrm{T}$ cells were functionally anergic [8], whereas in the second report they were functionally active ex vivo [9].

In marked contrast to most tumor antigen specific $\mathrm{T}$ cells which are not detectable ex vivo by multimer-assisted flow cytometry, an abundant repertoire of HLAA2/Melan-A/MART-1 multimer ${ }^{+} \mathrm{T}$ cells was identified. Indeed, we were able to trace the origin of this repertoire to a particularly efficient positive selection in the human thymus [19]. It appears that the large numbers of MelanA/MART-1 multimer ${ }^{+} \mathrm{T}$ cells are maintained throughout the adult life of healthy individuals at high numbers (on average approximately 1 in $1,400 \mathrm{CD} 8^{+} \mathrm{T}$ cells) in a functionally naïve state. Thus, $\mathrm{T}$ cells specific for the HLA-A2-Melan-A/MART-1 antigen are easily detectable by multimer staining directly ex vivo [20,21]. At some time during melanoma tumor progression some of these $\mathrm{T}$ cells are activated and recruited to the tumor site [22]. In PBMCs from melanoma patients, their mean frequency was not significantly different from that measured in healthy individuals but variable proportions of these cells exhibited an activated/memory phenotype. Remarkably, the mean frequency of Melan-A/ MART-1 multimer ${ }^{+} \mathrm{T}$ cells found in fresh metastatic lymph node cell suspensions was of 1 in 30 in two thirds of HLA-A2 melanoma patients, that is 25 -fold higher than in the peripheral blood. Moreover, close to $100 \%$ of these cells exhibited an activated/memory phenotype, characterized as CD45RA ${ }^{\text {low }}$ and $\mathrm{CCR} 7^{-}$. Thus, the Melan-A/MART-1 constitutes an excellent model antigen in humans to monitor the naturally acquired antitumoral T-cell responses as well as to precisely monitor the response elicited by various strategies of vaccination.

We have also assessed the Melan-A/MART-1-specific CD8 $\mathrm{T}$ cell response to experimental vaccination [23]. We conducted phase I clinical trials in advanced melanoma patients using Melan-A/MART-1 peptide, either the wild-type peptide or a modified peptide analogue, alone or in combination with immunological adjuvants. Peptides $(100 \mu \mathrm{g} /$ dose $)$ were injected at 4-week intervals, either alone or mixed with one of two adjuvants approved for human use: the AS02 (provided by GlaxoSmithKline, Belgium), which consists of the saponin QS21, monophosphoryl lipid A, and an oil-inwater emulsion; and Montanide (Seppic, Paris, France) which contains the mineral oil Drakeol and anhydro mannitol octadecanoate. To date we have completed the analysis of 49 vaccinated patients. All patients tolerated well the various vaccine formulations. Measurement of the frequency of A2/Melan-A/MART-1 multimer ${ }^{+}$ $\mathrm{CD} 8{ }^{+}$lymphocytes in blood samples obtained before and after peptide vaccination showed increases following vaccination in 13 patients. One patient, who received the wild-type Melan-A/MART-1 peptide with the AS02 adjuvant, had a 23 -fold expansion and reached a plateau frequency of A2/Melan-A/MART-1 multimer ${ }^{+}$lymphocytes of about $2 \%$ of the circulating $\mathrm{CD} 8^{+} \mathrm{T}$-cell compartment. The remaining patients had more modest expansions ranging between twofold and twelvefold the prevaccination multimer ${ }^{+} \mathrm{T}$-cell frequency. Interestingly, the latter were in the group immunized with peptide and Montanide. In fact, 12 out of 17 patients in this group had a detectable specific CTL response to peptide inoculation. Other clinical trials of vaccination with Melan-A/MART-1 and gp100 peptides have also shown the efficiency of Montanide as an adjuvant for CTL induction in melanoma patients [24, 25]. We also assessed the evolution of the cell surface phenotype of A2/Melan-A/MART-1 multimer ${ }^{+} \mathrm{T}$ lymphocytes over time after peptide vaccination. Interestingly, we could identify significant phenotype shifts in Melan-A/ MART-1-specific T cells in all five patients with detectable frequency increases. This consisted of up-regulation of HLA-DR and 2B4 as well as down-regulation of CD45RA, CCR7, and CD27 in variable proportions of multimer $^{+} \mathrm{T}$ lymphocytes [23].

A detailed analysis of the T-cell response in the patient who had the most marked increase in A2/Melan-A/ MART-1 multimer ${ }^{+} \mathrm{T}$ cells following immunization revealed interesting features that may provide valuable hints to future monitoring of cancer vaccines: (1) As assessed by ELISPOT and intracellular staining, the absolute number of Melan-A/MART-1-specific T cells able to secrete IFN- $\gamma$ increased $>50$-fold upon vaccination. This represented about $40 \%$ of the specific cells that could rapidly secrete IFN- $\gamma$, while no IL-4 production could be detected under the same experimental conditions [26]. When tested directly ex vivo after sorting from the postimmunization blood sample, Melan-A/ MART-1-specific cells were weakly cytolytic but became highly active after in vitro restimulation. Together, these results are in agreement with the effector cell surface phenotype of the specific cells. They indicate that large numbers of functionally active tumor-specific $\mathrm{CD} 8{ }^{+} \mathrm{T}$ cells could be obtained and maintained at high levels after in vivo activation by repeated peptide-based vaccination. (2) Importantly, we documented a distinct increase in the functional avidity of antigen recognition and in tumor reactivity in the postimmune Melan-A/ MART-1-specific populations as compared to the preimmune specific cells [27]. Improved antigen recognition correlated with an increase in the half-life of A2/peptide 
multimer interaction with the TCRs as assessed by kinetic analysis of A2/Melan-A/MART-1 multimer staining decay. (3) Ex vivo analysis of the TCR $\mathrm{V} \beta$ repertoire used by Melan-A/MART-1-specific CD8 ${ }^{+} \mathrm{T}$ cells at different time points during vaccination revealed that the response was the result of asynchronous expansion of several independent T-cell clones. Some of them could also be identified in TILs recovered from a metastatic tumor site excised during the vaccination period [27]. These data thus provide further evidence for a tumor peptide-driven immune response resulting in the selection of high avidity $\mathrm{T}$-cell clones of increased tumor reactivity that appear to evolve independently within oligoclonal populations of specific T cells. (4) Some subcutaneous and lymph node metastases regressed completely and even a lung metastasis underwent partial objective regression, while the remaining subcutaneous and visceral metastases were stabilized for a period of 1 year. Together, these results raise the possibility that a strong and systemic specific T-cell response may exert potent antitumor effects.

\section{Concluding remarks}

The 1980s were characterized by efforts to understand the role of $\mathrm{T}$ cell-mediated immunity in tumor recognition and culminated with the cloning of the first CTLdefined human tumor antigen in 1991 [28]. One decade later, a relatively large volume of clinical results with a variety of cancer vaccines based on molecularly defined tumor antigens has been acquired. Despite the relative success of vaccination at inducing specific immunity, clinical efficacy remains marginal. Thus, there are important hurdles to overcome to attain a high level of induced immunity in every vaccinated patient and, more importantly, good clinical efficacy. The number of parameters in the process of vaccine optimization is large and imposes the need to carry out a large number of exploratory clinical studies to discriminate between multiple possible vaccination strategies [29]. To quote only one recent example of the complexities involved in even the most simple form of vaccine delivery, the peptides, it was shown that the use of a 11 amino acid peptide instead of the exact 9 amino acid antigenic peptide led to the induction of a peptide-specific response biased for immunodominant epitope that is not expressed naturally by the tumor [30, 57]. Although preclinical studies in transgenic HLA mice, or even in nonhuman primates, might be of help, the most direct way remains to perform carefully planned phase I clinical trials of vaccination with defined tumor antigens. Only the systematic and standardized quantitative and qualitative monitoring of antigen-specific T-cell responses will allow us to make rapid progress towards optimal vaccination procedures in humans.

Great progress in monitoring antigen-specific class I-restricted T-cell responses in humans has been made in parallel with progress in human tumor immunology.
Nevertheless, monitoring of the local immune responses is still at its early stages. Recent studies have shown the feasibility of using fluorescent multimers in fresh or frozen tissue sections [31, 32, 33, 34]. Moreover, the limited amount of tumor material requires the adaptation of sensitive molecular tools to monitor gene expression in different clinical situations and identify potential correlates of immune responsiveness [35].

Multiple mechanisms of tumor escape from immune pressure have been well documented in recent years [36]. In fact, tumor escape has been identified as one of the major stumbling blocks in the search for clinically effective cancer vaccines [37]. Strategies targeting multiple tumor antigens and including T-cell help should help in coping with this problem. In this regard, the identification of tumor antigens targeted by CD4 T cells is progressing at a fast pace $[38,39]$. MHC class IIpeptide multimers are becoming available and should facilitate the monitoring of specific CD4 T-cell responses $[40,41]$. Finally, vaccination at the early stages of cancer progression may greatly minimize the chances for tumors to escape.

Acknowledgements This work was supported in part by funds from the NCCR Molecular Oncology.

\section{References}

1. Koff RS. (2002) Immunogenicity of hepatitis B vaccines: Implications for immune memory. Vaccine 20:3695

2. Koutsky LA, Ault KA, Wheeler CM, Brown DR, Barr E, Alvarez FB, Chiacchierini LM, Jansen KU, Pops Investigators (2002) A controlled trial of a human papillomavirus type 16 vaccine. N Engl J Med 347:1645

3. Das K, Gupta RK, Kumar V, Kar P (2003) Immunogenicity and reactogenicity of a recombinant hepatitis $\mathrm{B}$ vaccine in subjects over age of forty years and response of a booster dose among nonresponders. World J Gastroenterol 9:1132

4. Altman JD, Moss PA, Goulder PJ, Barouch DH, McHeyzerWilliams MG, Bell JI, McMichael AJ, Davis MM (1996) Phenotypic analysis of antigen-specific T lymphocytes. Science 274:94

5. Gallimore A, Glithero A, Godkin A, Tissot AC, Pluckthun A, Elliott T, Hengartner H, Zinkernagel R (1998) Induction and exhaustion of lymphocytic choriomeningitis virus-specific cytotoxic $\mathrm{T}$ lymphocytes visualized using soluble tetrameric major histocompatibility complex class I-peptide complexes. J Exp Med 187:1383

6. Pittet MJ, Zippelius A, Speiser DE, Assenmacher M, Guillaume P, Valmori D, Lienard D, Lejeune F, Cerottini JC, Romero P (2001) Ex vivo IFN-gamma secretion by circulating CD8 T lymphocytes: implications of a novel approach for T cell monitoring in infectious and malignant diseases. J Immunol $166: 7634$

7. Becker C, Pohla H, Frankenberger B, Schuler T, Assenmacher M, Schendel DJ, Blankenstein T (2001) Adoptive tumor therapy with $\mathrm{T}$ lymphocytes enriched through an IFN-gamma capture assay. Nat Med 7:1159

8. Lee PP, Yee C, Savage PA, Fong L, Brockstedt D, Weber JS, Johnson D, Swetter S, Thompson J, Greenberg PD, Roederer M, Davis MM (1999) Characterization of circulating T cells specific for tumor-associated antigens in melanoma patients. Nat Med 5:677

9. Valmori D, Scheibenbogen C, Dutoit V, Nagorsen D, Asemissen AM, Rubio-Godoy V, Rimoldi D, Guillaume P, 
Romero P, Schadendorf D, Lipp M, Dietrich PY, Thiel E, Cerottini JC, Lienard D, Keilholz U (2002) Circulating Tumorreactive $\mathrm{CD} 8(+) \mathrm{T}$ cells in melanoma patients contain a CD45RA(+)CCR7(-) effector subset exerting ex vivo tumorspecific cytolytic activity. Cancer Res 62:1743

10. Rufer N, Zippelius A, Batard P, Pittet M, Kurth I, Corthesy P, Cerottini JC, Leyvraz S, Roosnek E, Nabholz M, Romero P (2003) Ex-vivo characterization of human CD8 + T subsets with distinct replicative history and partial effector functions. Blood 102:1779

11. Liu L, Chahroudi A, Silvestri G, Wernett ME, Kaiser WJ, Safrit JT, Komoriya A, Altman JD, Packard BZ, Feinberg MB (2002) Visualization and quantification of $\mathrm{T}$ cell-mediated cytotoxicity using cell-permeable fluorogenic caspase substrates. Nat Med 8:185

12. Coulie PG, Karanikas V, Colau D, Lurquin C, Landry C, Marchand M, Dorval T, Brichard V, Boon T (2001) A monoclonal cytolytic T-lymphocyte response observed in a melanoma patient vaccinated with a tumor-specific antigenic peptide encoded by gene MAGE-3. Proc Natl Acad Sci USA 98:10290

13. Coulie PG, Lurquin C, Colau D, Connerotte T, Hanagiri T, van Pel A, Lucas S, Godelaine D, Lonchay C, Marchand M, van Baren N, Boon T (2002) Cytolytic T-cell responses of cancer patients vaccinated with a MAGE antigen. Immunol Rev 188:33

14. Smith JWI, Walker EB, Fox BA, Haley D, Wisner KP, Doran T, Fisher B, Justice L, Wood W, Vetto J, Maecker H, Dols A, Meijer S, Hu H-M, Romero P, Alvord WG, Urba WJ (2003) Adjuvant immunization of HLA-A2-positive melanoma patients with a modified gp100 peptide induces peptide-specific CD8 + T-cell responses. J Clin Oncol 21:1562

15. Valmori D, Pittet M, Vonarbourg C, Rimoldi D, Lienard D, Speiser D, Dunbar PR, Cerundolo V, Cerottini JC, Romero P (1999) Analysis of the cytolytic T lymphocyte response of melanoma patients to the naturally HLA-A*0201-associated tyrosinase peptide. Cancer Res 59:4050

16. Valmori D, Dutoit V, Rubio-Godoy V, Chambaz C, Lienard D, Guillaume P, Romero P, Cerottini JC, Rimoldi D (2001) Frequent cytolytic T-cell responses to peptide MAGEA10(254-262) in melanoma. Cancer Res 61:509

17. Valmori D, Dutoit V, Lienard D, Rimoldi D, Pittet MJ, Champagne P, Ellefsen K, Sahin U, Speiser D, Lejeune F, Cerottini JC, Romero P (2000) Naturally occurring human lymphocyte antigen-A2 restricted $\mathrm{CD} 8+\mathrm{T}$-cell response to the cancer testis antigen NY-ESO-1 in melanoma patients. Cancer Res 60:4499

18. Ayyoub M, Stevanovic S, Sahin U, Guillaume P, Servis C, Rimoldi D, Valmori D, Romero P, Cerottini JC, Rammensee HG, Pfreundschuh M, Speiser D, Levy F (2002) Proteasomeassisted identification of a SSX-2-derived epitope recognized by tumor-reactive CTL infiltrating metastatic melanoma. J Immunol 168:1717

19. Zippelius A, Pittet MJ, Batard P, Rufer N, de Smedt M, Guillaume P, Ellefsen K, Valmori D, Lienard D, Plum J, MacDonald HR, Speiser DE, Cerottini JC, Romero P (2002) Thymic selection generates a large $\mathrm{T}$ cell pool recognizing a self-peptide in humans. J Exp Med 195:485

20. Pittet MJ, Valmori D, Dunbar PR, Speiser DE, Lienard D, Lejeune $\mathrm{F}$, Fleischhauer $\mathrm{K}$, Cerundolo V, Cerottini JC, Romero P (1999) High frequencies of naive Melan-A/MART1 -specific $\mathrm{CD} 8(+) \mathrm{T}$ cells in a large proportion of human histocompatibility leukocyte antigen (HLA)-A2 individuals. J Exp Med 190:705

21. Romero P, Dunbar PR, Valmori D, Pittet M, Ogg GS, Rimoldi D, Chen JL, Lienard D, Cerottini JC, Cerundolo V (1998) Ex vivo staining of metastatic lymph nodes by class I major histocompatibility complex tetramers reveals high numbers of antigen-experienced tumor-specific cytolytic T lymphocytes. J Exp Med 188:1641

22. Pittet M, Zippelius A, Valmori D, Speiser D, Cerottini JC, Romero P (2002) Melan-A/MART-1-specific CD8 T cells: from thymus to tumor. Trends Immunol 23:325
23. Speiser D, Lienard D, Pittet M, Batard P, Rimoldi D, Guillaume P, Cerottini JC, Romero P (2002) In vivo activation of melanoma-specific $\mathrm{CD} 8(+) \mathrm{T}$ cells by endogenous tumor antigen and peptide vaccines. A comparison to virus-specific T cells. Eur J Immunol 32:731

24. Cormier JN, Salgaller ML, Prevette T, Barracchini KC, Rivoltini L, Restifo NP, Rosenberg SA, Marincola FM (1997) Enhancement of cellular immunity in melanoma patients immunized with a peptide from MART-1/Melan A. Cancer J Sci Am 3:37

25. Rosenberg SA, Yang JC, Schwartzentruber DJ, Hwu P, Marincola FM, Topalian SL, Restifo NP, Dudley ME, Schwarz SL, Spiess PJ, Wunderlich JR, Parkhurst MR, Kawakami Y, Seipp CA, Einhorn JH, White DE (1998) Immunologic and therapeutic evaluation of a synthetic peptide vaccine for the treatment of patients with metastatic melanoma. Nat Med 4:321

26. Pittet MJ, Speiser DE, Lienard D, Valmori D, Guillaume P, Dutoit V, Rimoldi D, Lejeune F, Cerottini JC, Romero P (2001) Expansion and functional maturation of human tumor antigen-specific CD8 $+\mathrm{T}$ cells after vaccination with antigenic peptide. Clin Cancer Res 7:796s

27. Valmori D, Dutoit V, Schnuriger V et al (2002) Vaccination with a Melan-A peptide selects an oligoclonal $\mathrm{T}$ cell population with increased functional avidity and tumor reactivity. J Immunol 168:4231

28. van der Bruggen $\mathrm{P}$, Traversari $\mathrm{C}$, Chomez $\mathrm{P}$, Lurquin $\mathrm{C}$, De Plaen E, Van den Eynde B, Knuth A, Boon T (1991) A gene encoding an antigen recognized by cytolytic $\mathrm{T}$ lymphocytes on a human melanoma. Science 254:1643

29. Moingeon P, Leclerc C (2002) Challenges and issues in new vaccine development. Trends Immunol 23:173

30. Dutoit V, Taub RN, Papadopoulos KP et al (2002) Multiepitope $\mathrm{CD} 8(+) \mathrm{T}$ cell response to a NY-ESO-1 peptide vaccine results in imprecise tumor targeting. J Clin Invest 110:1813

31. Haanen JB, van Oijen MG, Tirion F, Oomen LC, Kruisbeek AM, Vyth-Dreese FA, Schumacher TN (2000) In situ detection of virus- and tumor-specific T-cell immunity. Nat Med 6:1056

32. Skinner PJ, Daniels MA, Schmidt CS, Jameson SC, Haase AT (2000) Cutting edge: in situ tetramer staining of antigen-specific T cells in tissues. J Immunol 165:613

33. Andersen MH, Pedersen LO, Capeller B, Brocker EB, Becker JC, thor Straten P (2001) Spontaneous cytotoxic T-cell responses against survivin-derived MHC class I-restricted T-cell epitopes in situ as well as ex vivo in cancer patients. Cancer Res 61:5964

34. Dickinson AM, Wang XN, Sviland L, Vyth-Dreese FA, Jackson GH, Schumacher TN, Haanen JB, Mutis T, Goulmy E (2002) In situ dissection of the graft-versus-host activities of cytotoxic $\mathrm{T}$ cells specific for minor histocompatibility antigens. Nat Med 8:410

35. Wang E, Miller LD, Ohnmacht GA et al (2002) Prospective molecular profiling of melanoma metastases suggests classifiers of immune responsiveness. Cancer Res 62:3581

36. Marincola FM, Jaffee EM, Hicklin DJ, Ferrone S (2000) Escape of human solid tumors from T-cell recognition: molecular mechanisms and functional significance. Adv Immunol 74:181

37. Rosenberg SA (2001) Progress in human tumour immunology and immunotherapy. Nature 411:380

38. Gnjatic S, Atanackovic D, Jager E, Matsuo M, Selvakumar A, Altorki NK, Maki RG, Dupont B, Ritter G, Chen Y, Knuth A, Old LJ (2003) Survey of naturally occurring CD4 + T cell responses against NY-ESO-1 in cancer patients: Correlation with antibody responses. Proc Natl Acad Sci USA 100:8862

39. Wang RF (2002) Enhancing antitumor immune responses: intracellular peptide delivery and identification of MHC class II-restricted tumor antigens. Immunol Rev 188:65

40. Cameron TO, Norris PJ, Patel A, Moulon C, Rosenberg ES, Mellins ED, Wedderburn LR, Stern LJ (2002) Labeling antigen-specific CD4 $+\mathrm{T}$ cells with class II MHC oligomers. J Immunol Methods 268:51

41. Reijonen H, Kwok WW (2003) Use of HLA class II tetramers in tracking antigen-specific $\mathrm{T}$ cells and maping of T-cell epitopes. Methods 29:282 
42. Marchand M, van Baren N, Weynants P et al (1999) Tumor regressions observed in patients with metastatic melanoma treated with an antigenic peptide encoded by gene MAGE-3 and presented by HLA- A1. Int J Cancer 80:219

43. Jager E, Ringhoffer M, Dienes HP, Arand M, Karbach J, Jager D, Ilsemann C, Hagedorn M, Oesch F, Knuth A (1996) Granulocyte-macrophage-colony-stimulating factor enhances immune responses to melanoma-associated peptides in vivo. Int J Cancer 67:54

44. Reddish M, MacLean GD, Koganty RR, Kan-Mitchell J, Jones V, Mitchell MS, Longenecker BM (1998) Anti-MUC1 class I restricted CTLs in metastatic breast cancer patients immunized with a synthetic MUC1 peptide. Int $\mathrm{J}$ Cancer $76: 817$

45. Lee P, Wang F, Kuniyoshi J, Rubio V, Stuges T, Groshen S, Gee C, Lau R, Jeffery G, Margolin K, Marty V, Weber J (2001) Effects of interleukin-12 on the immune response to a multipeptide vaccine for resected metastatic melanoma. J Clin Oncol 19:3836

46. van Driel WJ, Ressing ME, Kenter GG et al (1999) Vaccination with HPV16 peptides of patients with advanced cervical carcinoma: clinical evaluation of a phase I-II trial. Eur J Cancer 35:946

47. Pinilla-Ibarz J, Cathcart K, Korontsvit T, Soignet S, Bocchia M, Caggiano J, Lai L, Jimenez J, Kolitz J, Scheinberg DA (2000) Vaccination of patients with chronic myelogenous leukemia with bcr-abl oncogene breakpoint fusion peptides generates specific immune responses. Blood 95:1781

48. Scheibenbogen C, Schmittel A, Keilholz U, Allgauer T, Hofmann U, Max R, Thiel E, Schadendorf D (2000) Phase 2 trial of vaccination with tyrosinase peptides and granulocyte- macrophage colony-stimulating factor in patients with metastatic melanoma. J Immunother 23:275

49. Muderspach L, Wilczynski S, Roman L, Bade L, Felix J, Small LA, Kast WM, Fascio G, Marty V, Weber J (2000) A phase I trial of a human papillomavirus (HPV) peptide vaccine for women with high-grade cervical and vulvar intraepithelial neoplasia who are HPV 16 positive. Clin Cancer Res 6:3406
50. Knutson KL, Schiffman K, Disis ML (2001) Immunization with a HER-2/neu helper peptide vaccine generates HER-2/neu CD8 T-cell immunity in cancer patients. J Clin Invest 107:477

51. Phan GQ, Touloukian CE, Yang JC et al (2003) Immunization of patients with metastatic melanoma using both class I- and class II-restricted peptides from melanoma-associated antigens. J Immunother 26:349

52. Bettinotti MP, Panelli M, Ruppe E, Mocellin S, Phan GQ, White DE, Marincola FM (2003) Clinical and immunological evaluation of patients with metastatic melanoma undergoing immunization with the HLA-Cw*0702-associated epitope MAGE-A12:170-178. Int J Cancer 105:210

53. Pullarkat V, Lee PP, Scotland R, Rubio V, Groshen S, Conway G, Lau R, Snively J, Sian S, Woulfe SL, Wolfe RA, Weber JS (2003) A phase I trial of SD-9427 (Progenipoietin) with a multipeptide vaccine for resected metastatic melanoma. Clin Cancer Res 9:1301

54. Tanaka S, Harada M, Mine T, Noguchi M, Gohara R, Azuma K, Tamura M, Yamada A, Morinaga A, Nishikori M, Katagiri K, Itoh K, Yamana H, Hashimoto T (2003) Peptide vaccination for patients with melanoma and other types of cancer based on pre-existing peptide-specific cytotoxic T-lymphocyte precursors in the periphery. $\mathrm{J}$ Immunother $26: 357$

55. Peterson AC, Harlin H, Gajewski TF (2003) Immunization with Melan-A peptide-pulsed peripheral blood mononuclear cells plus recombinant human interleukin-12 induces clinical activity and T-cell responses in advanced melanoma. $\mathrm{J}$ Clin Oncol 21:2342

56. Phan GQ, Yang JC, Sherry RM et al (2003) Cancer regression and autoimmunity induced by cytotoxic $\mathrm{T}$ lymphocyte-associated antigen 4 blockade in patients with metastatic melanoma. Proc Natl Acad Sci USA 100:8372

57. Gnjatic S, Jager E, Chen W, Altorki NK, Matsuo M, Lee SY, Chen Q, Nagata Y, Atanac Kovic D, Chen YT, Ritter G, Cebon J, Knuth A, Old LS (2002) CD8(+) T cell responses against a dominant cryptic HLA-A2 epitope after NY-ESO-1 peptide immunization of cancer patients. Proc Natl Acad Sci USA 99:11813 